\title{
PERKEMBANGAN NILAI, MORAL DAN SIKAP REMAJA
}

\author{
Zuldafrial
}

\begin{abstract}
Abstrak
Perkembanagan intelektual dalam kehidupan seseorang anak remaja harus diimbangi dengan nilai, moral serta akhlak yang baik. Anak yang tidak memiliki hubungan harmonis dengan orang tuanya di masa kecil kemungkinan besar tidak akan mampu mengembangkan superego yang cukup kuat, sehingga mereka bisa menjadi orang yang sering melanggar norma sosial. Kemandirian serta kematangan moral selalu mengedepankan dalam setiap tingkah laku dalam setiap kehidupan. Kemampuan yang ada dalam hidup seseorang anak menjadikan diri bisa memiliki akhlak serta sikap secara baik kedepannya.
\end{abstract}

Kata Kunci: Nilai, Moral, Remaja

\section{A. Pengertian Nilai, Moral Dan Sikap}

Antara pengetahuan dan tindakan ternyata tidak selalu terjadi korelasi positif. Proses pertumbuhan dan perkembangan pengetahuan menu bentuk sikap dan tingkah lakumerupakan proses kewajiban yang bersifat musikal. Seorang individu yang waktu tertentu melakukan perbuatan tercela ternyata tidak selalu karena ia tidak mengetahui bahwa perbuatan itu tercela, atau tidak sesuai dengan nilai dan norma sosial. Berbuat sesuatu secara fisik adalah bentuk tingkah laku yang mudah di lihat dan diukur. Akan tetapi, didalamnya tercakup juga sikap mental yang tidak selalu mudah ditanggapi, kecuali diduga dapat menggambarkan sikap mental tersebut.

Nilai-nilai adalah patokan-patokan yang berlaku dalam kehidupan masyarakat, misalnya adat kebiasaan dan sopan santun (Sutikna,1988:50) sopansantun, adat kebiasaan, dan nilai-nilai yang terkandung dalam pancasila adalah nilai-nilai hidup yang menjadi pegangan seluruh warga negara indonesia. Jadi, nilai adalah ukuran baik-buruk, benarsalah, boleh-tidak boleh, indah-tidak indah suatu prilaku atau pernyataan yang berlaku dalam kehidupan suatu kelompok masyarakat. Oleh kerna itu, nilai 
mendasari sikap dan prilaku seseorang dalam kehidupan di masyarakat.

Moral adalah ajaran tentang baikburuk suatu perbuatan dan kelakuan, akhlak, kewajiban, dan sebagainya (Purwadarminto: 1950: 957). Dalam moral diatur segala perbuatan yang dinilai baik dan perlu dilakukan, serta sesuatu perbuatan yang dinilai tidak baik dan perlu dihindari. Moral berkaitan dengan kemampuan seseorang untuk membedakan antara perbuatan yang benar dan yang salah. Dengan demikian, moral juga mendasari dan mengendalikan seseorang dalam bersikap dan bertingkah laku.

Sebagai pendidik, misalnya, kesadaran akan adanya hubungan antar semua bagian perkembangan ini, bermanfaat untuk perencanaan kurikulum untuk berbagai kelompok usia anak. Kurikulum untuk bayi, anak-anak yang baru belajar berjalan dan anak usia prasekolah hampir dipastikan digerakan oleh kebutuhan untuk mendukung perkembangan yang sehat pada semua bagian diri anak. Sementara untuk anakanak usia sekolah dasar perencanaan kurikulum diarahkan sebagai usahausaha untuk membantu anak-anak mengembangkan pemahamanpemahaman konseptual yang dapat diaplikasikan pada mata pelajaran yang dipelajari.
Perkembangan anak berlangsung dalam sebuah tahapan yang relatif teratur di mana kemampuan-kemampuan, keterampilan-keterampilan, dan pengetahuan-pengetahuan lanjut anak terbangun atas kemampuan-kemampuan, keterampilan-keterampilan, dan pengetahuan-pengetahuan anak sebelumnya. Riset-riset perkembangan manusia menunjukkan bahwa tahapantahapan pertumbuhan dan perubahan anak usia 9 tahun pertama rentang kehidupan relatif stabil dan dapat diprediksikan tahapannya (Piaget 1952; Erikson 1963; Dyson \& Genishi 1993; Gallahue 1993; Case \& Okamoto 1996).

Perubahan-perubahan yang dapat diramalkan ini terjadi pada semua bagian perkembangan-fisik, emosi, sosial, bahasa, dan kognitif-meskipun bagaimana perubahan-perubahan ini mewujud dan makna yang dilekatkan pada perubahan tersebut mungkin bervariasi menurut kontek budaya.

Pengetahuan mengenai perkembangan yang khas untuk setiap rentang usia anak membantu para orangtua atau pendidik untuk mempersiapkan lingkungan belajar dan merencanakan tujuan-tujuan kurikulum yang reaslistik dan pengalamanpengalaman belajar yang tepat menurut perkembangan anak. 
Perolehan

perkembangan

bervariasi untuk setiap anak, termasuk untuk keberfungsian semua dimensi perkembangan dalam diri anak. Keragaman individual paling tidak dalam dua makna: keragaman dari ratarata/normatif arah perkembangan dan keunikan setiap anak sebagai individu (Sroufe, Cooper, \& DeHart 1992).

Setiap anak adalah seorang pribadi unik dengan pola dan waktu pertumbuhan bersifat individual, sebagaimana halnya untuk kepribadian, temperamen, gaya belajar, latar belakang dan pengalaman keluarga. Semua anak memiliki kelebihan, kebutuhan-kebutuhan, dan minat-minat masing-masing; sejumlah mungkin memiliki kebutuhan belajar dan perkembangan yang khusus. Pemahaman tentang keragaman yang luas bahkan pada anak-anak usia kronologis (usia yang dihitung sejak anak lahir) yang sama, hendaknya mengantarkan kita pada kesadaran bahwa usia anak hanyalah sebuah gambaran kasar untuk kemasakan perkembangan anak.

Pengakuan bahwa keragaman individual bukan hanya diharapkan tapi juga dihargai menuntut kita sebagai orang dewasa ketika berinteraksi dengan anakanak memperlakukan mereka secara tepat dengan keunikannya masingmasing. Penekanan perlakuan anak secara individual sesuai dengan keunikan masing-masing anak tidaklah sama dengan "individualisme." Alih-alih demikian, pengakuan ini menuntut kita untuk tidak menganggap anak hanya sebagai anggota kelompok usia, kemudian mengharapkan mereka untuk menampilkan tugas-tugas perkembangan kelompok usia tersebut tanpa mempertimbangkan keragaman kemampuan adaptasi setiap individu anak.

Memiliki pengharapan tinggi terhadap anak adalah penting, tetapi memiliki harapan-harapan yang kaku menurut norma kelompok tidak mencerminkan kenyataan yang terjadi bahwa adanya perbedaan yang nyata dalam perkembangan dan belajar individual anak dalam tahun-tahun awal kehidupan. Harapan norma kelompok dapat memberi dampak yang sangat merusak terutama untuk anak-anak dengan kebutuhan perkembangan dan belajar yang khusus (NEGP 1991; Mallory 1992; Wolery, Strain, \& Bailey 1992).

Pengalaman-pengalaman awal memberikan pengaruh yang bersifat kumulatif maupun tertunda terhadap perkembangan anak; ada periode-periode optimal untuk jenis-jenis perkembangan dan belajar tertentu. Pengalamanpengalaman awal anak, baik positif atau negatif, bersifat kumulatif dalam arti 
bahwa jika sebuah pengalaman frekuensi kejadiannya jarang, maka hal tersebut juga memiliki pengaruh minimal. Jika pengalaman-pengalaman positif atau negatif sering terjadi, mereka memberikan dampak yang sangat kuat, lama, dan bahkan memiliki dampak seperti bola salju (Katz \& Chard 1989; Kostelnik, Soderman, \& Whiren 1993; Wieder \& Greenspan 1993).

Sebagai contoh, pengalaman seorang anak prasekolah bersama anakanak dalam tahun-tahun prasekolah membantu dia mengembangkan keterampilan-keterampilan sosial dan kepercayaan diri yang memungkinkan dia memiliki teman-teman/persahabatan dalam tahun-tahun pertama sekolah dan pengalaman-pengalaman ini selanjutnya menguatkan kompetensi sosialnya. Sebaliknya, anak-anak yang gagal untuk mengembangkan kompetensi sosial minimal dan diabaikan atau ditolak teman-teman sebayanya memiliki resiko tinggi untuk drop out sekolah, menjadi anak-anak dan remaja nakal, dan menunjukkan permasalahan kesehatan mental ketika mereka dewasa (Asher, Hymel, \& Renshaw, 1984; Parker \& Asher 1987).

Pola-pola yang sama dapat diamati pada bayi-bayi yang menangis dan menunjukkan usaha-usaha sejenis dalam berkomunikasi yang ditanggapi secara teratur, memiliki kemampuan komunikasi yang baik. Demikian juga, ketika anak-anak memiliki atau tidak memiliki pengalaman literasi sejak dini, seperti dibacakan secara teratur, keberhasilan mereka selanjutnya dalam belajar membaca sangat dipengaruhi oleh hal tersebut. Mungkin yang paling meyakinkan adalah hasil-hasil penelitian yang menunjukkan bahwa pengalamanpengalaman sosial dan sensorik motorik selama tiga tahun pertama kehidupan secara langsung mempengaruhi perkembangan neurologis otak, dengan implikasi-implikasi penting dan menetap terhadap kapasitas-kapasitas anak untuk belajar (Dana Alliance for Brain Initiatives 1996).

Pengalaman-pengalaman awal juga dapat memberi pengaruh yang bersifat menunda, baik positif atau negatif, terhadap perkembangan selanjutnya. Sejumlah bukti menyarankan bahwa mengandalkan penguatan ekstrinsik (dari luar) seperti permen atau uang untuk membentuk perilaku anak, merupakan sebuah strategi yang efektif dalam jangka pendek, sementara motivasi intrinsik (dari dalam) lebih efektif untuk membentuk perilaku dalam jangka panjang (Dweck 1986; Kohn 1993). Sebagai contoh, memberi uang kepada anak untuk membaca dalam jangka panjang merusak keinginan anak untuk 
membaca sebagai kesenangan dan budaya.

Pada dimensi tertentu dalam rentangan kehidupan, beberapa bentuk perkembangan dan belajar terjadi sangat optimal. Sebagai contoh, tiga tahun pertama kehidupan menjadi periode paling optimal untuk perkembangan bahasa verbal (Kuhl 1994). Meskipun keterlambatan-keterlambatan dalam perkembangan bahasa, baik karena kerusakan fisik atau lingkungan, dapat diperbaiki kemudian, penanganan sejenis menuntut pertimbangan-pertimbangan tersebut. Demikian juga, tahun-tahun prasekolah tampaknya menjadi periode optimal untuk perkembangan motorik yang mendasar dan karenanya keterampilan-keterampilan motorik mendasar lebih mudah dan lebih efisien dicapai pada periode usia ini (Gallahue 1995).

Anak-anak yang memiliki banyak kesempatan dan dukungan orang dewasa untuk mempraktekkan keterampilanketerampilan motorik besar (berlari, melompat, melempar, dll) selama periode ini memiliki keuntungan kumulatif menjadi lebih baik dan mampu dalam menguasai keterampilan-keterampilan motorik yang lebih kompleks pada tahun-tahun berikutnya. Sebaliknya, anak-anak yang memiliki pengalaman awal terbatas kemungkinan besar mengalami kesulitan untuk menguasai kompetensi fisik dan menunjukkan keterlambatan ketika mencoba berpartisipasi dalam aktivitasaktivitas olahraga tingkat lanjut.

Perkembangan berjalan dalam arah yang dapat diprediksikan menuju sebuah kondisi yang lebih kompleks, lebih terorganisasi, dan lebih terinternalisasi. Belajar selama periode anak usia dini berlangsung dari pengetahuan yang berbentuk perilaku menuju pengetahuan yang berbentuk simbolik (Bruner 1983).

Sebagai contoh, anak-anak belajar untuk mengenali rumah mereka dan tempat-tempat lain yang mereka kenal lebih dahulu sebelum mereka dapat memahami kata-kata kiri dan kanan atau membaca peta sebuah rumah. Programprogram yang tepat menurut tahapan perkembangan menyediakan banyak kesempatan kepada anak-anak untuk memperluas dan memperdalam pengetahuan mereka yang bersifat pengetahuan dengan menyediakan sebuah pengalaman langsung yang bervariasi dan membantu anak-anak menguasai pengetahuan yang bersifat simbolik melalui representasi pengalaman-pengalaman mereka dalam media yang beragam seperti menggambar, melukis, menyusun model, bermain drama, deskripsi-deskripsi verbal dan tertulisa (Katz1995). 
Bahkan setiap anak yang masih kecil mampu untuk menggunakan beragam media untuk merepresentasikan konsep-konsep pemahaman mereka. Lebih lanjut, melalui representasi pengetahuan mereka, pengetahuan itu sendiri menjadi meningkat (Edwards, Gandini, \& Forman 1993; Malaguzzi 1993;Forman 1994). Representasi modalitas sensori (baca panca indera) dan media juga bervariasi menurut usia anak. Sebagai contoh, kebanyakan bayi dan anak yang baru belajar berjalan kebanyakan belajarnya menggunakan panca indera dan motorik, tetapi anakanak usia 2 tahun menggunakan satu benda melakukan satu hal dalam bermain (sebuah kotak untuk menelepon atau menggunakan sendok sebagai gitar).

Dalam kaitannya dengan nilai, moral merupakan kontrol dalam bersikap dan bertingkah laku sesuai dengan nilainilai hidup yang di maksud. Misalnya dalam pengamalan nilai tenggang rasa, dalam prilakunya seseorang akan selalu memerhatiakn perasaan orang lain, sehingga tidak berbuat sekhendak hatinya. Nilai-nilai kehidupan menyangkut persoalan baik dan buruk, sehingga berkaitan dengan moral.

Dalam hal ini aliran psikoanalisis tidak membedakan antara moral,norma, dan nilai (Sarlito,1991:91). Semua konsep itu menurut Freud menyatu dalam kongsepnya tentang Superego. Superego dalam teori freud merupakan bagian dari jiwa yang berfungsi untuk mengendalikan tingkah laku (ego) sehingga tidak bertentangan dengan nilai-nilai masyarakat.

$$
\text { Adapun sikap menurut }
$$
Gerungan, Secara umum diartikan sebagai kesedian bereaksi individu terhadap sesuatu. Sikap ini berkaitan dengan motif dan mendasari tingkah laju seseorang. Tingkah laku yang dapat terjadi dan akan diperbuat seseorang dapat diramal jika diketahui sikapnya. Sikap belum merupakan suatu tindakan, tetapi baru merupakan kecebrungan. Jadi, sipat merupakan kesiapan untuk beraaksi terhadap suatu objek sebagai hasil penghayatan terhadap objek tertentu. Dengan kata lain, nilai perlu di kenal kan terlebih dahulu, kemudian dihayati dan didorong oleh moral, baru akan terbentuk sikap tertentu dan akhirnya terwujud perilaku sesuai dengan nilai-nilai yang dimaksud.

\section{B. Karakteristik Nilai, Moral Dan Sikap Remaja}

Sejauh mana remaja dapat mengamalkan nilai-nilai yang anutnya dan yang telah dicontohkan kepada mereka ? Salah satu tugas perkembangan yang harus dilakukan remaja adalah mempelajari apa yang diharapkan oleh 
kelompok dari masyarakatnya. Remaja diharapkan mengganti konsep-konsep moral yang berlaku umu dan merumuskannya kedalam kode moral yang akan berfungsi sebagai pedoman perilakunya.

Michael mengemukakan lima perubahan dasar moral yang harus dilakukan oleh remaja, yaitu sebagai berikut.

a. Pandangan moral individu makin lama menjadi lebih abstrak.

b. Keyakinan moral lebih berpusat pada apa yang benar dan yang kurang pada apayang salah.

c. Penilaian moral yang semakin kognitif mendorong remaja untuk berani mengambil kepurusan terhadap berbagai masalah moral yang dihadapinya.

d. Penilaian moral secara psikologis menjadi lebih mahal dalam arti bahwa penilaian moral menimbulkan ketegabgab emosi.

Hubungan antara tahap-tahap tersebut bersifat hierarkis, yaitu tiap tahap berikutnya berlandaskan tahap-tahap sebelumnya, yang lebih terdiferensiasi dan operasi-operasinya terintegrasi dalam struktur baru. Oleh karena itu, rangkaian tahapmembentuk suatu urutan dari struktur yang semakin di beda-bedakan dan diintegrasikan untuk memenuhi fungsi yang sama, yakni menciptakan pertimbangan moral menjadi semakin memadai terhadap dilema moral. Tahaptahap yang lebih rendah dilampaui dan diintergrasikan kembali oleh tahap yang lebih tinggi. Reintegrasim ini berati bahwa pribadi yang berbeda pada tahap moral yang lebih tinggi, mengerti pribadi pada moral yang lebih rendah.

Selanjutnya, penelitian lintas budaya yang dilakukan di Turki, Israel, Kanada, Inggris, Malaysia, Taiwan, dan Meksiko memberikan kesan kuat bahwa urutan tahap yang tetap dan tidak dapat dibalik itu juga bersifat universal, yakni berlaku untuk semua orang dalam priode historis atau kebudayaan apa pun.

Menurut Kohlbrg, penelitian empirisnya memperhatikan bahwa tidak setiap individu akan mencapai tahap tertinggi, melainkan hanya minoritas saja, yaitu hanya $\quad 5$ sampai $10 \%$ dari seluruh penduduk, bahkan angka ini pun masih diragukan kemudian. Diakuinya pula bahwa untuk sementara waktu, orang dapat jatuh kembali pada tahap moral yang lebih rendah, yang disebut sebagai "regresi fungsional".

Perkembangan dan belajar terjadi dalam dan dipengaruhi oleh kontek social cultural yang majemuk. Bronfenbrenner (1979, 1989, 1993) menyediakan sebuah model ekologis untuk memahami perkembangan manusia. Bronfenbrenner menjelaskan bahwa perkembangan anak 
paling baik dipahami dalam kontek keluarga, setting pendidikan, komunitas, dan masyarakat yang lebih luas. Kontekkontek yang beragam ini berhubungan satu sama lain dan semuanya memiliki pengaruh terhadap anak yang sedang berkembang. Sebagai contoh, bahkan seorang anak diasuh dalam keluarga yang mencintai dan mendukungnya, komunitas yang sehat dipengaruhi oleh bias-bias masyarakat yang lebih luas, seperti rasisme atau seksisme, dan kemungkinan memperlihatkan pengaruh negatif dari stereotif negative dan diskriminasi.

Kultur merupakan pola-pola keyakinan dan perilaku, baik eksplisit dan implisit, yang diwariskan kepada generasi penerusnya oleh masyarakat atau kelompok social, kelompok religi, atau kelompok etnis di mana mereka tinggal. Karena kultur seringkali didiskusikan dalam kontek diversitas atau multikulturalisme, orang seringkali gagal untuk mengenali peran dominan yang yang dimainkan budaya dalam mempengaruhi perkembangan semua anak-anak. Setiap budaya menstruktur dan memaknai perkembangan dan perilaku anak (Edwards \& Gandini 1989; Tobin, Wu, \& Davidson 1989; Rogoff et al. 1993). Sebagaimana yang dikemukakan Bowman, "aturan-aturan perkembangan adalah sama untuk semua anak, tetapi kontek-kontek social membentuk perkembangan anak ke dalam konfigurasi-konfigurasi yang berbeda" (1994, 220). Guru-guru anak usia dini perlu memahami pengaruh kontek-kontek sosiokultural dalam belajar, mengenali kompetensi yang sedang berkembang pada anak-anak, dan menerima sebuah cara yang beragam pada anak-anak untuk mengekspresikan pencapaianpencapaian perkembangan yang mereka peroleh (Vygotsky 1978; Wertsch 1985; Forman, Minick, \& Stone 1993; New 1993, 1994; Bowman \& Stott 1994; Mallory \& New 1994a; Phillips 1994; Bruner 1996; Wardle 1996).

Para guru seharusnya mempelajari budaya dari mayoritas anak didik terutama budaya mereka memiliki budaya yang berbeda dengan peserta didiknya. Meskipun demikian, mengakui bahwa perkembangan dan belajar dipengaruhi oleh kontek-kontek social dan cultural bukan berarti menuntut para guru untuk memahami semua nuansa setiap budaya yang mereka temui dalam praktek-praktek mereka; hal ini akan menjadi tugas yang tidak mungkin. Lebih dari itu, pengakuan fundamental ini membuat para guru peka terhadap kebutuhan untuk mengakui bagaimana pengalaman cultural yang mereka miliki membentuk perspektif mereka dan untuk menyadari bahwa perspektif yang 
majemuk harus dipertimbangkan dalam keputusan-keputusan tentang perkembangan dan belajar anak-anak.

Anak-anak mampu belajar untuk berfungsi di dalam lebih satu kontek budaya secara simultan. Meskipun demikian, jika para guru menetapkan ekspektasi-ekspektasi yang rendah untuk anak-anak berdasarkan budaya dan bahasa rumah mereka, anak-anak tidak dapat berkembang dan belajar secara optimal. Pendidikan seharusnya merupakan sebuah proses yang memiliki nilai tambah. Sebagai contoh, anak-anak yang bahasa utamanya bukan bahasa Inggris seharusnya mampu untuk belajar bahasa Inggris tanpa dipaksa untuk menyerah pada bahasa ibu mereka (NAEYC 1996a). Demikian juga, anakanak yang terbiasa memakai bahasa Inggris mendapatkan keuntungan dari belajar bahasa lainnya. Tujuannya adalah bahwa semua anak belajar untuk berfungsi dengan baik dalam masyarakat secara keseluruhan dan bergerak secara nyaman di antara kelompok orang-orang yang memiliki latarbelakang yang sama maupun berbeda.

Anak-anak adalah pembelajar aktif, mengalami langsung pengalaman fisik dan sosial sebagaimana halnya pengetahuan yang ditransmisikan secara kultural untuk menyusun pemahamanpemahaman mereka sendiri tentang dunia yang ada di sekitar mereka. Anakanak memiliki kontribusi terhadap perkembangan dan belajar mereka sendiri sebagaimana halnya mereka berusaha untuk menanggapi pengalaman-pengalaman harian mereka di rumah, program usia dini dan komunitas. Prinsip-prinsip dari praktek yang sesuai dengan tahapan perkembangan didasarkan pada teoriteori dominan yang memandang bahwa perkembangan intelektual dari sebuah perspektif konstruktivis-interaktif (Dewey 1916; Piaget 1952; Vygotsky 1978; DeVries \& Kohlberg 1990; Rogoff1990; Gardner 1991; Kamii \& Ewing 1996).

Sejak lahir, anak-anak secara aktif terlibat dalam menyusun pemahamanpemahan mereka sendiri dari pengalaman-pengalaman dan pemahaman-pemahaman ini dimediasi oleh dan secara pasti terhubungan kepada kontek sosiokultural. Anak-anak usia dini secara aktif belajar dari mengamati dan berpartisipasi dengan anak-anak dan orang dewasa lain, termasuk di dalamnya adalah para orangtua dan para guru. Anak-anak membentuk hipotesis mereka sendiri dan membuktikannya melalui interaksi sosial, manipulasi fisik, dan melalui prosesproses berpikir mereka sendirimengamati apa yang terjadi, merefleksikan dalam temuan-temuan 
mereka, mengajukan pertanyaanpertanyaan, dan memformulasikan jawaban-jawaban. Ketika objek-objek, peristiwa-peristiwa, dan orang-orang lain menunjukkan hal yang berbeda dengan model yang secara mental telah tersusun dalam diri anak, anak dipaksa untuk menyesuaikan model atau mengubah struktur mental untuk mempertimbangkan informasi baru. Selama masa usia dini, anak-anak secara kontinyu memproses pengalaman-pengalaman baru untuk membentuk ulang, memperluas, dan mereorganisasi struktur-struktur mental (Piaget 1952; Vygotsky 1978; Case \& Okamoto 1996). Ketika para guru dan orang dewasa menggunakan berbagai strategi untuk mendorong anak-anak melakukan refleksi atas pengalamanpengalaman mereka melalui sebuah perencanaan, maka pengetahuan dan pemahaman yang diperoleh menjadi mendalam (Copple, Sigel, \& Saunders 1984; Edwards, Gandini, \& Forman 1993; Stremmel \& Fu 1993; Hohmann \& Weikart 1995).

Dalam pernyataan prinsip ini, istilah pengalaman fisik dan sosial digunakan dalam kontek yang luas termasuk ekspose anak terhadap pengetahuan fisik, belajar melalui pengalaman menggunakan benda-benda (mengamati bahwa bola yang dilempar ke udara jatuh kembali), dan pengetahuan sosial, termasuk hal-hal penting yang secara kultural ditransmisikan agar anakanak berfungsi dengan baik di dunia ini. Sebagai contoh, anak-anak secara progresif menyusun pemahaman mereka atas berbagai symbol, akan tetapi yang mereka gunakan (seperti system alphabet atau numeric) merupakan sesuatu yang ditransmisikan kepada mereka oleh orang-orang dewasa dalam budaya mereka.

\section{Dalam tahun-tahun belakangan} ini, diskusi-diskusi mengenai perkembangan menjadi terpolarisasi (lihat Seifert 1993). Teori Piaget menekankan bahwa perkembangan struktur kognitif tertentu merupakan prasyarat bagi belajar (contoh perkembangan mempengaruhi belajar), sementara penelitian lainnya telah mendemonstrasikan bahwa pengajaran tentang konsep-konsep spesifik atau strategi-strategi dapat memfasilitasi perkembangan struktur kognitif menjadi lebih matang (belajar mempengaruhi perkembangan) (Vygotsky 1978; Gelman \& Baillargeon 1983).

Usaha-usaha terkini untuk mengatasi dikotomi yang jelas ini (Seifert 1993; Sameroff \& McDonough 1994; Case \& Okamoto 1996) mengakui bahwa esensinya kedua perspektif teoritis tersebut adalah benar dalam menjelaskan aspek-aspek perkembangan kognitif selama usia dini. Pengajaran yang 
strategis tentu saja dapat meningkatkan belajar anak-anak. Dengan demikian, pengajaran langsung kemungkinan besar tidak efektif dan gagal jika tidak disesuaikan dengan pengetahuan dan kapasitas-kapasitas kognitif anak dalam setiap tahapan perkembangannya.

Perkembangan dan belajar merupakan hasil interaksi antara maturasi biologis dan lingkungan, baik fisik maupun sosial, di mana anak-anak tinggal di dalamnya. Prinsip ini menunjukkan bahwa manusia merupakan produk hereditas (biologis) dan lingkungan dan kedua kekuatan ini berhubungan satu sama lain.

Para penganut behavioris (aliran perilaku) memfokuskan pada pengaruhpengaruh lingkungan sebagai penentu belajar, sementara para penganut maturasionis (aliran kemasakan biologis) menekankan pentingnya hereditaskarakteristik biologis bawaan. Setiap perspektif benar sampai tingkatan tertentu dan selebihnya keduanya tidak mampu untuk menjelaskan belajar atau perkembangan. Sekarang ini, perkembangan dilihat sebagai hasil dari proses transaksional yang interaktif antara individu yang sedang tumbuh dan berkembang dengan pengalamanpengalaman dalam lingkungan fisik dan sosial (Scarr \& McCartney 1983; Plomin 1994a, b).
Sebagai contoh, sebuah bawaan genetik kemungkinan memprediksi pertumbuhan yang sehat, tetapi nutrisi yang tidak mencukupi dalam tahun-tahun awal kehidupan mengganggu terpenuhinya potensi tersebut. Disabilitas yang parah, baik disebabkan hereditas atau lingkungan, kemungkinan dapat diperbaiki melalui intervensi yang sistematik dan tepat. Demikian juga halnya, seorang anak dengan temperamen yang dibawanya-sebuah kecenderungan psikologi dalam menanggapi situasi tertentu-membentuk dan dibentuk oleh bagaimana anak-anak lain dan orang-orang dewasa berkomunikasi dengan anak tersebut

Bermain merupakan sebuah instrumen penting bagi perkembangan sosial, emosional, dan kognitif anak-anak, juga sebagai sebuah refleksi atas perkembangan mereka. Memahami bahwa anak adalah konstruktorkonstruktor aktif atas pengetahuan yang dimiliki dan bahwa perkembangan dan belajar sebagai hasil proses interaktif, para guru anak usia dini mengakui bahwa bermain bagi anak merupakan sebuh kontek yang sangat mendukung untuk proses-proses perkembangan tersebut (Piaget 1952; Fein 1981; Bergen 1988; Smilansky \& Shefatya 1990; Fromberg 1992; Berk \& Winsler 1995). 
Bermain memberi anak-anak kesempatan-kesempatan

untuk memahami dunia, berinteraksi dengan orang lain dalam cara-cara yang secara sosial diterima, mengekspresikan dan mengontrol emosi-emosi, dan mengembangkan kapabilitas-kapabilitas simbolik mereka. Permainan anak memberi orang-orang dewasa pencerahan-pencerahan atas perkembangan anak-anak dan kesempatan-kesempatan untuk mendukung pengembangan strategistrategi baru. Vygotsky (1978) meyakini bahwa bermain mengarahkan perkembangan, sebagai contoh, permainan simbolik dapat mempromosikan perkembangan abilitasabilitas representasi simbolik. Bermain menyediakan sebuah kontek bagi anakanak untuk mempraktekkan keterampilanketerampilan yang baru dikuasai dan juga berfungsi sebagai sudut pengembangan kapasitas-kapasitas untuk menjalankan peran-peran sosial yang baru, mencoba tugas-tugas yang baru atau yang menantang, dan memecahkan permasalahan yang komplek yang mungkin bisa atau tidak akan bisa mereka tangani (Mallory \& New 1994).

Penelitian menunjukkan pentingnya permainan sosiodrama sebagai bagian dari kurikulum belajar untuk anak-anak usia 3 sampai 6 tahun.
Ketika para guru menyediakan sebuah organisasi tematik untuk bermain, menawarkan dukungan, ruang, dan waktu yang tepat, dan menjadi lebih terlibat dalam permainan dengan memperluas dan mengelaborasi atas gagasangagasan anak, maka bahasa dan keterampilan-keterampilan literasi anak dapat ditingkatkan (Levy, Schaefer, \& Phelps 1986; Schrader 1989, 1990; Morrow 1990; Pramling 1991; Levy, Wolfgang, \& Koorland 1992). Selain mendukung perkembangan kognitif, bermain juga menyediakan sejumlah fungsi penting bagi perkembangan fisik, emosi, dan sosial anak-anak (Herron \& Sutton-Smith 1971). Anak-anal mengungkapkan dan merepresentasikan gagasan-gagasan, pemikiran-pemikiran, dan perasaan-perasaan mereka ketika terlibat dalam bermain simbolik. Selama bermain, seorang anak belajar untuk mengatasi emosi, untuk berinteraksi dengan orang lain, untuk mengatasi konflik-konflik, dan untuk mendapatkan perasaan kompeten. Melalui bermain, anak-anak juga dapat mengembangkan imajinasi-imajinasi dan kreativitaskreativitas mereka. Oleh karena itu, inisiatif anak dan dukungan guru dalam bermain merupakan komponen esensial dalam praktek yang sesuai dengan tahapan perkembangan anak (Fein \& Rivkin 1986). 


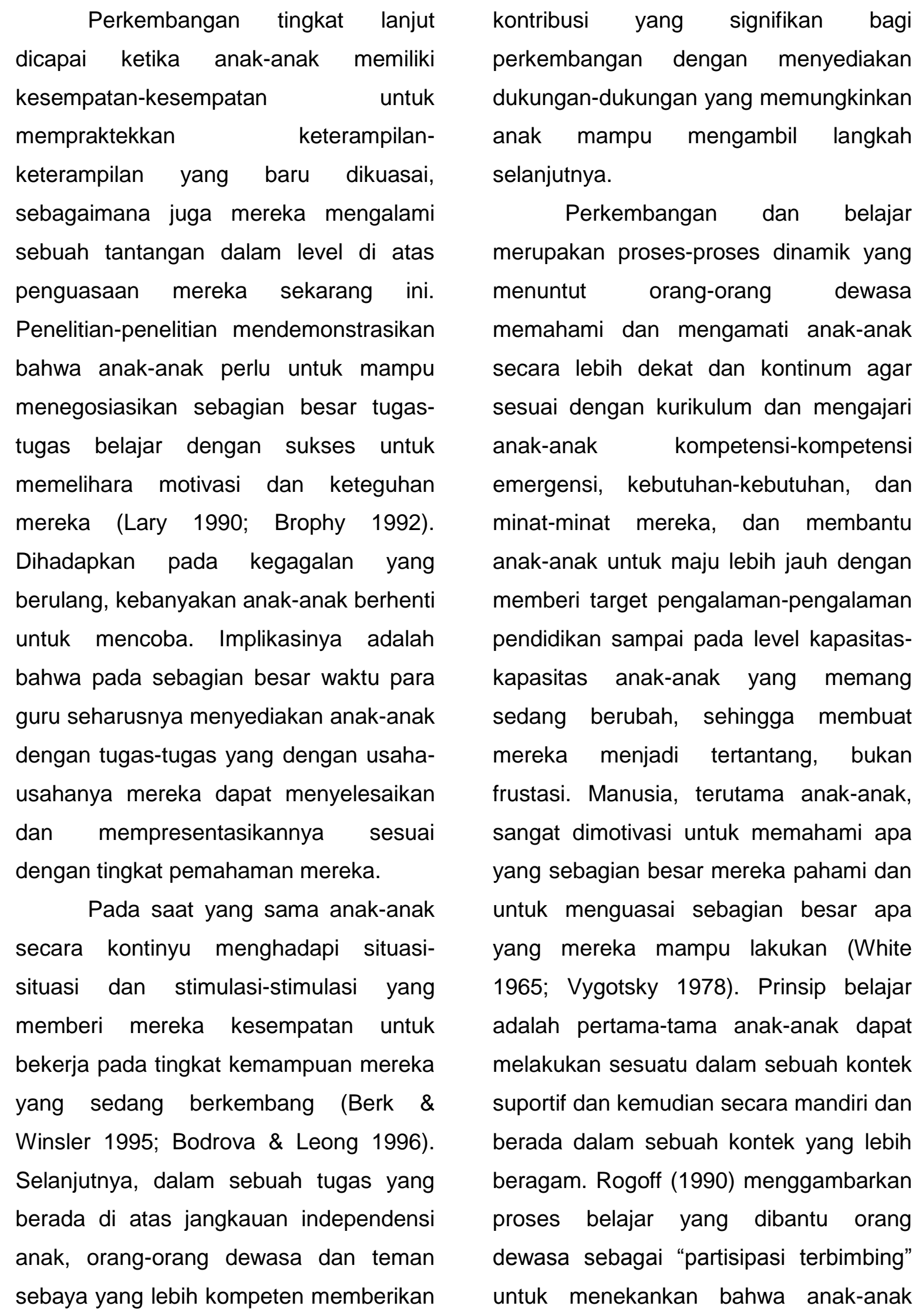


secara aktif berkolaborasi dengan orang lain untuk bergerak maju menuju sebuah level pemahaman dan keterampilan yang lebih kompleks.

Anak-anak menunjukkan caracara yang berbeda dalam mengetahui dan belajar, dan cara-cara yang berbeda dalam merepresentasikan apa yang mereka ketahui. Pada kurun waktu tertentu, para teoritisi belajar dan ahli psikologi perkembangan telah mengakui bahwa manusia terlahir untuk memahami dunia dalam cara-cara yang beragam dan bahwa setiap individu cenderung memiliki preferensi atau model belajar tertentu. Studi-studi perbedaan dalam modalitas belajar telah menemukan hal yang kontras antara pembelajar visual, auditori, atau taktil. Sementara karya yang lain telah mengidentifikasi jenis pembelajar mandiri atau dependen (Witkin 1962).

Gardner (1983) memperluas konsep ini dengan berteori bahwa manusia paling tidak memiliki tujuh "intelegensi." Sebagai tambahan terhadap kecerdasan tradisional yang penting bagi keberhasilan sekolah yaitu kecerdasan bahasa dan logika matematis, setiap individu paling tidak memiliki kecerdasan dalam bidang-bidang lain: musikal, spasial, kinestetik tubuh, intrapersonal dan interpersonal. Malaguzzi (1993) menggunakan metaphor "100 bahasa" untuk menggambarkan modalitas yang beragam yang digunakan anak-anak untuk memahami dunia dan merepresentasikan pengetahuan mereka. Proses-proses merepresentasikan pemahaman yang mereka miliki, dengan bantuan guru-guru, dapat membantu anak-anak memperdalam, memperbaiki, dan memperluas pemahaman mereka (Copple, Sigel, \& Saunders 1984; Forman 1994; Katz 1995).

Prinsip modalitas yang beragam memberi implikasi bahwa para guru seharusnya menyediakan bukan hanyak kesempatan-kesempatan setiap anak secara individual menggunakan preferensi model belajarnya sebagai menjadi modal kekuatan mereka (HaleBenson 1986) tetapi juga kesempatankesempatan untuk membantu anak-anak mengembangkan intelegensi-intelegensi yang mereka sadari tidak begitu menonjol.

Anak-anak berkembang dan belajar dengan sangat baik dalam kontek sebuah komunitas di mana mereka aman dan dihargai, kebutuhan-kebutuhan fisik mereka terpenuhi, dan mereka merasa secara psikologis aman. Maslow(1954) mengkonseptualisasikan sebuah hierarki kebutuhan-kebutuhan dimana belajar tidak mungkin terjadi kecuali kebutuhankebutuhan fisiologis dan psikologis untuk aman terpenuhi lebih dahulu. Karena keamanan dan kesehatan fisik sekarang- 
sekarang ini seringkali terancam, program-program untuk anak usia dini harusnya bukan hanya menyediakan nutrisi, keamanan, dan kesehatan yang adekuat tapi juga pastikan layananlayanan yang lebih komprehensif, seperti fisik, gigi, kesehatan mental, sosial (NASBE 1991; U.S. Department of Health \& Human Services 1996).

Perkembangan anak-anak dalam semua bagiannya dipengaruhi oleh abilitas mereka untuk membangun dan memelihara sebuah hubungan primer yang positif secara konsisten dengan orang-orang dewasa dan anak-anak yang lain (Bowlby 1969; Stern 1985; Garbarino et al. 1992). Hubungan-hubungan primer ini berawal dalam keluarga tetapi kemudian meluas seiring berjalannya waktu termasuk guru-guru anak-anak dan anggota-anggota komunitas; oleh karena itu, praktek-praktek yang sesuai dengan tahapan perkembangan seharusnya memperhatikan dengan baik kebutuhankebutuhan fisik, sosial, dan emosi sebagaimana halnya perkembangan intelektual.

\section{Faktor-Faktor Yang Mempengaruhi Perkembangan Nilai, Moral Dan Sikap}

Perkembangan internalisasi nilainilai terjadi melalui identifikasi dengan orang-orang yang dianggap sebagai model. Bagi anak-anak usia 12 dan 16 tahun gambaran ideal yang diidentifikasikan adalah orang-orang dewasa yang beribawa atou simpatik, orang-orang terkenal,dan hal-hal yang ideal yang diciptakannya sendiri.

Menurut ahli psikoanalisis, nilai dan moral menyatu dalam kongsep superego. Superego di bentuk melalui jalan internalisasi larangan-larangan atau perintah-perintah yang datang dari luar (khususnya dari orang tua). Oleh kerena itu, anak yang tidak memiliki hubungan harmonis dengan orang tuanya di masa kecil kemungkinan besar tidak akan mampu mengembangkan superego yang cukup kuat, sehingga mereka bisa menjadi orang yang sering melanggar norma sosial.

Berdasarkan penelitian empiris yang dilakukan Kohlberg pada tahun 1958, sekaligus menjadi disertai doctornya dengan judul The Developmental of Mode of Moral Think and Choice in the years 10 to 16 , seperti tertuang dalam buku tahap-tahap perkembangan Moral (1995), tahap-tahap perkembangan moral dapat di bagi sebagai berikut:

\section{a. Tingkat Prakonvesional}

Pada tingkat ini, anak tanggap terhadap aturan-aturan buda dan 
terhadap ungkapan ungkapan budaya mengenai baik dan buruk, benar dan salah. Akan tetapi hal ini semata-mata di tafsirkan dari segi sebab akibat fisik atau kenikmatan perbuatan (hukum, keuntungan, pertukaran, dan kebaikan). Tingkat ii dapat dibagi menjadi dua tahap:

\section{Tahap orientasi hukuman dan kepatuhan}

Akibat-akibat fisik suatu perbuatan menentukan baik buruknya, tanpa menghiraukan arti dan nilai manusiawi dari akibat tersebut. Anak semata-mata menghindarkan hukuman dan pada kekuasaan tanpa mempersoalkannya. Jika ia berbuat "baik", hal itu karena anak meniali tindakannya sebagai hal yang bernilai dalam dirinya sendiri dan bukan karena rasa hormat terhadap tatanan moral yang melandasi dan didukung oleh hukuman dan otoritas.

\section{Tahap orientasi relativitis-instrumental}

Perbuatan yang benar adalah

cara atau alat unutk memuaskan kebutuhannya sendiri dan kadang-kadang juga kebutuhan orang lain. Hubungan antarmanusia dipandang seperti hubungan di pasar (jual-beli). Terdapat elemen kewajaran tindakan yang bersifat resiproksitas (timbal-balik) dan pembagian sama rata, tetapi ditafsirkan secara fisik dan pragmatis. Resiproksitas ini merupakan tercemin dalam bentuk "jika engkau menggaruk punggungku, atau juga akan menggaruk punggungmu". Jadi, perbuatan baik tidaklah didasarkan karena loyalitas, terima kasih ataupun keadilan.

\section{Tingkat Konvensional}

Pada tingkat ini, anak hanya menuruti harpaan keluarga, kelompok atau bangsa. la memandang bahwa hal tersebut bernilai bagi dirinya sendiri, tanpa menghindahkan akibat yang segera dan nyata. Sikapnya bukan hanya konformitas terhadap harapan pribadi dan tata tertib sosial, melainkan juga loyal (setia) terhadapnya dan secara aktif mempertahankan, mendukung dan membenarkan seluruh tata-tertib atau norma tersebut serta mengindetifikasikan diri dengan orang atau kelompok yang terlibat didalamnya. Tingkat ini memiliki dua tahap :

\section{Tahap orientasi kesepakatan antarpribadi atau orientasi}

Perilaku yang baik adalah yang menyenangkan dan membantu orang lain serta yang disetujui oleh mereka. Pada tahap ini terdapat banyak konformitas terhadap gambaran steorotif mengenai perilaku mayoritas atau "alamiah". Perilaku sering dinilai menurut niatnya, ungkapan "dia bermaksud baik" unutk 
pertama kalinya menjadi penting. Orang mendapatkan persetujuan dengan baik.

\section{Tahap orientasi hukuman dan ketertiban}

Terdapat orientasi terhadap otoritas, aturan yang tetap dan penjagaan tata tertib/norma-norma sosial. Periliaku yang baik adalah semata-mata melakukan kewajiban sendiri, menghormati otoritas dan menjaga tata tertib sosial yang ada, sebagai yang bernilai dalam dirinya sendiri.

\section{b. Tingkat pasca-konvensional (otonom/berlandaskan prinsip)}

Pada tingkat ini terdapat usah yang jelas untuk merumuskan nilai-nilai dan prinsip moral yang memiliki keabsahan dan dapat diterapkan, terlepas dari otoritas kelompok atau oarang yang berpegang pada prinsip-prinsip itu dan terlepas pula dari identifikasi individu sendiri dengan kelompok tersebut. Ada dua tahap pada tingkat ini, yaitu :

\section{Tahap orientasi kontrak sosial legalitas}

Pada umumnya tahap ini amat bernada semangat utillitarian. Perbuatan yang baik cenderung dirumuskan dalam kerangka hak dan ukuran individual umum yang telah diuji secara kritis dan telah disepakati oleh seluruh masyarakat.
Terdapat kesadaran yang jelas mengenai relativitas nilai dan pendapat pribadi sesuai dengannya. Terlepas dari apa yang telah disepakati secara konstitusional dan demokratis, hak adalah soal "nilai" dan "pendapat" pribadi.

Hasilnya adalah penekanan pada sudut pandang ilegal, tetapi dengan penekanan apda kemungkinan untuk mengubah hukum berdasarkan pertimbangan rasional mengenai manfaat sosial (jadi, bukan membekukan hukum itu sesuai dengan tata tertib gaya seperti yang terjadi pada tahap 4). Diluar bidang hukum yang disepakati, berlaku persetujuan bebas ataupun kontrak. Inilah "moral resmi" dari pemerintah dan perundang-undangan yang berlaku di setiap negara.

\section{Tahap orientasi prinsip etika yang berlaku disetiap negara}

Hak ditentukan oleh keputusan suara batin, sesuai denga prinsip-prinsip etis yang dipilih sendiri dan yang mengacu pada komprehensivitas logis, universalitas, konsistensi logis. Prinsipprinsip ini bersifat abstrak dan etis (kaidah emas imperative kategoris) dan mereka tidak merupakan peraturan moral konkret seperti kesepuluh Perintah Allah. Pada hakikat inilah prinsip-prinsip universal keadilan, resiproksitas dan persamaan hak asasi manusia serta rasa hormat 
terhadap manusia sebagai pribadi individual.

Berdasarkan penelitian empirisnya tersebut, secara kreatif Kohlberg menggabungkan berbagai dari Dewey dan Piaget, bahkan berhasil melampaui gagasan-gagasan mereka. Dengan kata lain ia berhasil mengoreksi gagasan Piaget mengenai tahap perkembangan moral yang dianggap terlalu sederhana.

Kohleberg secara tentative menguraikan sendiri tahap-tahap 4, 5, dan 6 yang ditambahkan pada tiga tahap awal yang telah dikembangkan oleh Piaget. Dewey pernah membagi proses perkembangan moral atas tiga tahap : tahap pramoral, tahap konvesional, dan tahap otonom. Selanjutnya, Piaget berhasil melukiskan dan menggolongkan seluruh pemikiran moral anak seperti kerangka pemikiran Dewey, (1) pada tahap pramoral, anak belum menyadari keterikatannya pada aturan; (2) tahap konvesional dicirikan dengan ketaatan pada kekeuasaan; (3) tahap otonom bersifat terikat pada aturan yang didasarkan pada resiproksitas (hubungan timbal-balik). Berkat pandangan Dewey dan Piaget, Kohleberg berhasil memperlihatkan 6 tahap pertimbangan moral anak dan remaja seperti yang tertera diatas.

Teori-teori lain yang nonpsikoanalisis beranggapan bahwa hubungan anak-orangtua bukan satusatunya sarana pembentukan moral. Para sosiolog beranggapan bahwa masyarakat mempunyai peranan penting dalam pembentukan moral. Tingkah laku yang terkendali disebabkan oleh adanya kontrol dari masyarakat itu sendiri yang mempunyai sanksi-sanksi tersendiri buat sipelanggar (Sarlito, 1992:2).

Dalam usaha membentuk perilaku sebagai percerminan nilai-nilai hidup tertentu, jelas bahwa factor lingkungan memegang peranan penting. Di antara segala unsur lingkungan sosial yang berpengaruh adalah manusia-manusia yang langsung dikenal oleh seseorang sebagai perwujudan dari nilai-nilai tertentu. Dalam hal ini lingkungan sosial terdekat adalah orang tua dan guru mereka.

Teori perkembangan moral yang dikemukakan oleh Kohleberg menunjukan bahwa sikap moral bukan hasil sosialisasi yang diperoleh dari kebiasaan dan hal-hal lain yang berhubungan dengan nilai kebudayaan. Tahap-tahap perkembangan moral terjadi dari aktivitas spontan pada masa anak-anak (Singgih Gunarsa, 1990:2). Anak memang berkembang melalui interaksi sosial, tetapi interaksi ini mempunyai corak yang khusus dan factor pribadi anak ikut berperan. 


\section{Kemandirian Sebagai Kebutuhan Psikologis Pada Remaja}

Setiap manusia dilahirkan dalam kondisi yang tidak berdaya, ia akan bergantung pada orang tua dan orangorang yang berada dilingkungannya hingga waktu tertentu. Seiring denga berlalunya waktu dengan perkembangan selanjutnya, seorang anak perlahan-lahan akan melepaskan diri dari ketergantungannya pada orang tua atau orang lain disekitarnya dan belajar untuk mandiri. Hal ini merupakan suatu proses alamiah yang dialami oleh semua mahluk hidup, tidak terkecuali manusia. Mandiri atau sering juga disebut berdiri diatas kaki sendiri merupakan kemampuan seseorang untuk tidak bergantung pada orang lain serta bertanggung jawab atas apa yang dilakukannya. Kemandirian dalam konteks individu tentu memiliki aspek yang lebih luas dari sekedar aspek fisik.

\section{E. Penutup}

Nilai-nilai adalah patokan-patokan yang berlaku dalam kehidupan masyarakat, misalnya adat kebiasaan dan sopan santun (Sutikna,1988:50) sopansantun, adat kebiasaan, dan nilai-nilai yang terkandung dalam pancasila adalah nilai-nilai hidup yang menjadi pegangan seluruh warga negara indonesia. Jadi, nilai adalah ukuran baik-buruk, benarsalah, boleh-tidak boleh, indah-tidak indah suatu prilaku atau pernyataan yang berlaku dalam kehidupan suatu kelompok masyarakat. Oleh kerna itu, nilai mendasari sikap dan prilaku seseorang dalam kehidupan di masyarakat.

$\begin{array}{rlr}\text { Moral berkaitan dengan } \\ \text { kemampuan } & \text { seseorang untuk }\end{array}$
membedakan antara perbuatan yang benar dan yang salah. Dengan demikian, moral juga mendasari dan mengendalikan seseorang dalam bersikap dan bertingkah laku.

Dalam kaitannya dengan nilai, moral merupakan kontrol dalam bersikap dan bertingkah laku sesuai dengan nilainilai hidup yang di maksud. Misalnya dalam pengamalan nilai tenggang rasa, dalam prilakunya seseorang akan selalu memerhatiakn perasaan orang lain, sehingga tidak berbuat sekhendak hatinya. Nilai-nilai kehidupan menyangkut persoalan baik dan buruk, sehingga berkaitan dengan moral.Setiap manusia dilahirkan dalam kondisi yang tidak berdaya , ia akan bergantung pada orang tua dan orang-orang yang berada dilingkungannya hingga waktu tertentu. Seiring denga berlalunya waktu dengan perkembangan selanjutnya, seorang anak perlahan-lahan akan melepaskan diri dari ketergantungannya pada orang tua atau 
orang lain disekitarnya dan belajar untuk mandiri.

\section{F. Daftar Pustaka}

Abu Ahmadi. 1983. "Pisikologi Umum". Cet. I. Surabaya:PT. Bina IImu.

Al-MighwarB Andi Mappiare. 1982. "Psikologi Remaja".Surabaya: Usaha Nasional.

Al-Kautsar. 2003. "Psikologi”.Jakarta: Depdikbud dan PT. Rineka cipta.

Branca Albert A. 1965. "Psychology". USA: Allyn And Bacon Inc.

Muhammad. 2008. "Psikologi Remaja" .Bandung:CV. Pustaka Setia.

Elizabeth

B. Hurlock. 1968.

"Develovmental Psychology". (edisi ke Tiga). New York: Mc. Graw Hull.

Enung Fatimah. 2006. "Psikologi Perkembangan”. Bandung: Pustaka Setia.

Gunarsa, S.D. 1988. "Psikologi Remaja". Jakarta: BPK Gunung Mulia.

Hurlock, E. B. 1990. "Developmental psychology: a lifespan approach". Boston.

Husdarta\&Saputra $\quad$ Y.M. 1999. "Perkembangan Peserta Didik". Jakarta: DEPDIKBUDMcGraw-Hill.

Linda L Davidoff. 1988. "Psikologi Suatu Pengantar". Jakarta: Erlangga.

M. Asrori. 2008. "Perkembangan Peserta Didik". Pontianak: Untan Press.
Muhammad Mighwar. 2006. "Psikologi Remaja”. Bandung: Pustaka Setia. Monks, F.J., Knoers, A. M. P., Haditono, S. R. 1991. "Psikologi perkembangan : Pengantar dalam berbagai bagiannya (cetakan ke-7)". Yogyakarta: Gajah Mada University Press.

Mustaqim. 2001. "Psikologi Pendidikan". Semarang: Pustaka Pelajar.

M. Jamaluddin Munfuzh. 2001. "Psikologi Anak dan Renaja Muslim, (Alih Bahasa) Abdul Rosyad Rifai, Melly Sri Sulastri”.Jakarta:Psikologi Perkembangan Remaja. PT Bina Aksara.

Sarlito Wirawan Sarwono. 1989. "Psikologi Remaja". Jakarta: Rajawali.

Soerjono Soekanto. 1989. "Remaja dan Permasalahannya". Jakarta: Rajawali.

Sunarto, dkk. 1999. "Perkembangan

Peserta Didik'. Jakarta: Pusat Perbukuan Syaikh

Toenggoel P. Siagian.1985. "Pendekatan

Pokok dalam Mempertimbangkan Remaja Masa Kini”. Prisma.

Utami Munandar. 1992. "Mengembangkan Bakat dan Kreativitas Anak Sekolah". Jakarta: Gramedia Widiasarana Indonesia. Zulkifli, L. 1986. "Psikologi Remaja". Bandung: Remaja Karya. 